\title{
Design Procedures for Fiber Composite Box Beams
}

Christos C. Chamis

Lewis Research Center

Cleveland, Ohio

and

Pappu L.N. Murthy

Cleveland State University

Cleveland, Ohio

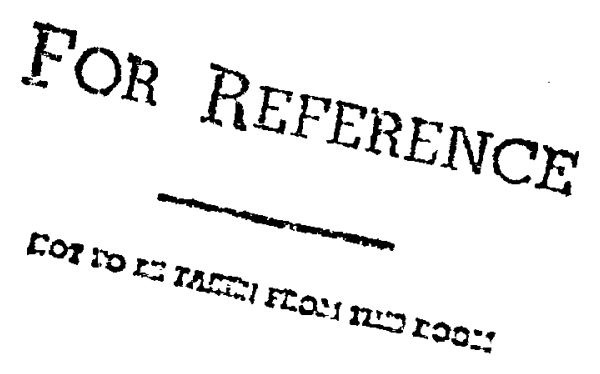

February 1988

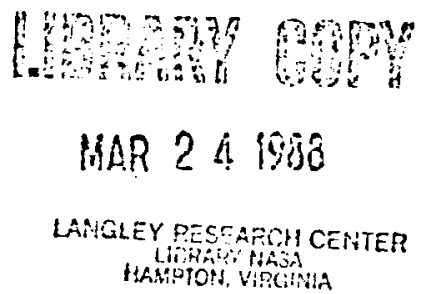





\title{
DESIGN PROCEDURES FOR FIBER COMPOSITE BOX BEAMS
}

\author{
Christos C. Chamis* \\ National Aeronautics and Space Administration \\ Lewis Research Center \\ Cleveland, Ohio 44135
}

and

Pappu L.N. Murthyt

Cleveland State University

Civil Engineering Department

Cleveland, Ohio 44115

\section{SUMMARY}

Step-by-step procedures are described which can be used for the preliminary design of fiber composite box beams subjected to combined loadings. These procedures include a collection of approximate closed-form equations so that all the required calculations can be performed using pocket calculators. Included is an illustrative example of a tapered cantilever box beam subjected to combined loads. The box beam is designed to satisfy strength, displacement, buckling, and frequency requirements.

\section{INTRODUCTION}

The design of fiber composite structural components requires analysis methods and procedures which relate the structural response of the component to the specified loading and environmental conditions. Subsequently, the structural response is compared to given design criteria for strength, displacement, buckling, vibration frequencies, etc. in order to ascertain that the component will meet all the design requirements and will perform satisfactorily.

An important class of structural components that can readily be made using fiber composites are box beams. Box beams are generally used to span long distances and to resist combined loads. Box beams are the ma in structural components in aircraft wings. They are made using thin flat/curved laminates, are designed to resist the loads primarily through membrane action and are designed to have constant or tapered cross sections. In addition, the laminate thickness for the covers and sides can be different and varied along the span. In a previous paper (ref. 1) step-by-step procedures were described for the preliminary design of composite panels subjected to combined loadings. These procedures have since been extended for the preliminary design of composite box beams. The objective of this paper is to describe these extended procedures.

These procedures include a collection of simple equations to expedite the various calculations performed during the preliminary design phase. These procedures are demonstrated by applying them to a preliminary design of a tapered cantilever box beam. The box beam is subjected to combined loads at the free end. It is designed to meet strength, displacement, buckling, and frequency

* Senior Aerospace Structures/Composites Engineer.

†Senior Research Fellow Aerospace Structures/Composites. 
requirements. The various steps in these procedures are described in detail with ample explanatory notes so that they can be used to aid in the preliminary design of built-up composite structural components in general.

\section{SAMPLE DESIGN}

It is necessary to have as complete a definition of the specific design as is possible in order to initiate the preliminary design phase. For the illustrative example described herein, this definition consists of the following.

1. Structural Component:

Cantilever, 3-bay box beam (schematics figs. I and 2).

2. Specified Loads:

Free end static loads (fig. 1).

6600 lb vertical; 3300 lb lateral; 100000 lb in twist moment.

3. Displacement Limits:

Tip displacements less than 1.5-percent of length; angle of twist less than $1^{\circ}$.

4. Frequencies:

Flap greater than 100 cycle/sec, edge greater than 150 cycle/sec; twist greater than $450 \mathrm{cycle} / \mathrm{sec}$.

Local panel frequencies to be greater than box beam global frequencies.

5. Safety Factor:

2.0 times specified load.

6. Composite System:

As graphite fiber in epoxy matrix (AS/E) about 0.6 fiber volume ratio.

7. Design Procedure/Requirements:

Box beam not to exceed displacement limits.

Laminates in various bays not to exceed ply fiber-controlled strengths at design loads or ply matrix controlled strengths at specified loads.

Composite panels in each bay not to exceed combined stress buckling.

8. General philosophy on preliminary design of composite box beams:

Size covers for only the vertical load and add plies for the combined loads (lateral and twist moment). 
Size side walls for only the lateral load and add plies for the combined loads (vertical and twist moment).

\section{STEP-BY-STEP DESIGN PROCEDURE}

Once the design is defined to the extent just outlined, we are ready to design the composite laminates for the covers and the walls of the box beam by following the step-by-step design procedure.

\section{Step 1: Identify Design Variables}

Number of plies, ply orientation and stacking sequence for the composite covers and side walls for the three different bays.

\section{Step 2: Establish Design Loads}

Safety factor times specified loads (fig. 1):

$N_{c x x}=2 \times$ vertical load $(66001 \mathrm{lb})=13200 \mathrm{lb}$

$N_{\text {cyy }}=2 \times$ lateral load $(3300 \mathrm{lb})=6600 \mathrm{lb}$

$M_{C X x}=2 \times$ twist moment $(100000 \mathrm{ib}$ in. $)=200000 \mathrm{lb}$-in.

\section{Step 3:}

Obtain composite material properties ( $p l y$ and $\pm \theta$ angleply) for AS/E from table $I$ and figures 3 and 4 .

\section{Step 4:}

Select laminate configurations for box beam covers and side walls in each of the three bays.

(a) Calculate in-plane membrane loads at the bulkhead locations (figs. I and 2): These loads are calculated by dividing the moment at that section by the respective depth and width.

At span station 0 :

covers:

$$
\begin{aligned}
N_{C X X} & =P_{Z} \times l /(h \times w) \\
& =132001 \mathrm{~b} \times 60 \mathrm{in.} /(10 \mathrm{in.} \times 20 \mathrm{in.}) \\
& =3960 \mathrm{lb} / \mathrm{in} .
\end{aligned}
$$


wal1s:

$$
\begin{aligned}
N_{\text {cyy }} & =P_{y} \times \ell /(h \times w) \\
& =6600 \mathrm{lb} \times 60 \mathrm{in} . / 20 \mathrm{in.} \times 10 \mathrm{in} . \\
& =1980 \mathrm{lb} / \mathrm{in} .
\end{aligned}
$$

covers:

$$
\begin{aligned}
N_{\text {cxy }}= & \pm M_{x} /\left[(w \times h) \text { covers }+(w \times h)_{\text {side walls }}\right] \\
+ & P_{y} / w_{\text {covers }} \\
= & \pm 2000001 \mathrm{~b}-\mathrm{in.} /[(20 \mathrm{in.} \times 10 \mathrm{in.}) \\
+ & (10 \mathrm{in.} \times 20 \mathrm{in.})] \\
+ & 6600 \mathrm{lb} /(2 \times 20 \mathrm{in.}) \\
= & -335 \mathrm{lb} / \mathrm{in} . \text { (top cover) } \\
& 665 \mathrm{lb} / \mathrm{in} . \text { (bottom cover) }
\end{aligned}
$$

walls:

$$
\begin{aligned}
N_{C Z X} & = \pm M_{x} /\left[(w \times h)_{\text {covers }}+(w \times h)_{\text {side walls }}\right] \\
& \left.+P_{y} / h_{\text {side }} \text { wa }\right] 1 \mathrm{~s} \\
& = \pm 2000001 \mathrm{~b}-\mathrm{in.} /[(20 \mathrm{in.} \times 10 \mathrm{in.}) \\
& +(10 \mathrm{in.} \times 20 \mathrm{in.})] \\
& +13200 \mathrm{lb} /(2 \times 10 \mathrm{in.}) \\
& =160 \mathrm{lb} / \mathrm{in} .(\text { front wall) } \\
& =1160 \mathrm{lb} / \mathrm{in} . \text { (back wall) }
\end{aligned}
$$

Repeating the calculations for the other span stations and summarizing in table form, we have the results shown in table 2 .

(b) Design bottom cover (pressure surface, figs. 1 and 2). This surface is in tension. We need to use the longitudinal tensile strength. Number of $0^{\circ}$ plies $\mathrm{N}_{\ell O}=$ Design load $\left(\mathrm{N}_{C \times x}\right) /($ longitudinal tensile strength $\left(s_{\ell} 11 t=220000 \mathrm{psi}\right) \times$ ply thickness $\left.\left(t_{\ell}=0.005 \mathrm{in.}\right)\right)$.

$$
N_{\ell 0}=\frac{N_{c x x}}{s_{\ell 11 T} t_{\ell}}=\frac{+39601 \mathrm{~b} / \mathrm{in} .}{2200001 \mathrm{~b} / \mathrm{sq} \mathrm{in} . \times 0.005 \mathrm{in} .}=3.6 \approx 4 .
$$

Number of $\pm 45^{\circ}$ plies $N_{\ell \pm 45}=$ Design load $\left(N_{C x y}\right) x$ one-half the ratio of the ply longitudinal modulus ( $E_{\ell l 1}=18.5 \mathrm{mps}$ ) to $\pm 45^{\circ}$ composite shear modulus $\left(\mathrm{G}_{\theta 12}=5.8 \mathrm{mpsi}\right) /$ longitudinal compressive strength $\left(\mathrm{S}_{\ell} 1 \mathrm{lc}_{\mathrm{c}}=180000 \mathrm{psi}\right) \mathrm{x}$ ply thickness $\left(t_{\ell}=0.005\right.$ in.) 


$$
N_{\ell \pm 45}=\frac{N_{c x y} \times(1 / 2)\left(E_{\ell 11} / G_{\theta 12}\right)}{s_{\ell 11 c} \times t_{l}}=\frac{665 \mathrm{lb} / \mathrm{in}(1 / 2(18.5 / 5.8)}{180000 \mathrm{lb} / \mathrm{sq} \mathrm{in.} \times 0.005 \mathrm{in.}}=1.16 \approx 2
$$

The number of plies is rounded up since plies are available in fixed thicknesses. Number of $90^{\circ}$ plies $N_{l} 90$ : Note there is no $N_{c y y}$ design load and therefore no $90^{\circ} \mathrm{plies}$ are needed. However, we will use two plies for laminate integrity and improved buckling resistance. Therefore,

$$
N_{\ell} 90 \approx 2
$$

Thus, the laminate configuration for the bottom cover is eight plies as follows 4 at $0^{\circ}, 2$ at $\pm 45^{\circ}$ and 2 at $90^{\circ}$. Note that this is not a symmetric laminate.

(c) Design top cover (suction surface figs. 1 and 2 ). This surface is in compression. We need to use the longitudinal compression strength to determine the number of zero plies.

$$
N_{l O}=\frac{N_{C X X}}{s_{l 11 C^{t}}}=\frac{-3960 \mathrm{lb} / \mathrm{in} .}{180000 \mathrm{lb} / \mathrm{sq} \mathrm{in.} \times 0.005 \mathrm{in} .}=4.4 \approx 4
$$

The number of $\pm 45^{\circ}$ plies is now determined from the ratio:

$$
\begin{aligned}
N_{\ell \pm 45} & =\frac{N_{c x y} \text { (Top) }}{N_{c x y} \text { (Bottom) }} \times 1.16 \text { plies } \\
& =\frac{335}{665} \times 1.16=0.58 \approx 1 \rightarrow \text { use two plies for a balanced lamimate } \\
N_{\ell} 90 & =2 \text { (same reason as for bottom cover) }
\end{aligned}
$$

Therefore, the top cover is an eight-ply laminate same as bottom cover.

(d) Design side wall (leading edge (front), figures 1 and 2 , and loads from table step 4.2 )

$$
\begin{aligned}
& N_{\ell 0}=\frac{N_{C x x}}{S_{\ell 11 t \times} t_{\ell}}=\frac{1980 \mathrm{lb} / \mathrm{in} .}{220000 \mathrm{lb} / \mathrm{sq} \mathrm{in} . \times 0.005 \mathrm{in} .}=1.8 \approx 2 \\
& N_{\ell \pm 45} \frac{N_{c x y}(1 / 2)\left(E_{\ell 11} / \mathrm{G}_{\theta 12}\right)}{S_{\ell 11 c} \times t_{\ell}} \\
&= \frac{160 \mathrm{lb} / \mathrm{in} .(1 / 2)(18.5 / 5.8)}{180000 \mathrm{lb} / \mathrm{in}^{2} \times 0.005 \mathrm{in} .}=0.3 \mathrm{plies} \rightarrow \text { use two plies } \\
& N_{\ell 90}=2 \text { (same reason as for covers) }
\end{aligned}
$$

(e) Design side wall (trailing edge (back) figures 1 and 2 and loads from table step 4.2 ) 


$$
\begin{aligned}
N_{\ell 0} & =\frac{N_{c x x}}{S_{\ell 11 c} \times t_{\ell}}=\frac{-1980 \mathrm{lb} / \mathrm{in} .}{180000 \mathrm{lb} / \mathrm{sq} \mathrm{in.} \times 0.005 \mathrm{in} .}=2.1 \approx 2 \\
N_{\ell \pm 45} & =\frac{N_{c x y}}{S_{\ell 11 c} \times t_{\ell}}=\frac{1160 \mathrm{lb} / \mathrm{in} .}{180000 \mathrm{lb} / \mathrm{sq} \mathrm{in} \times 0.005 \mathrm{in} .}=1.3 \approx 2 \\
N_{\ell 90} & =2 \text { (same reasons as for covers) }
\end{aligned}
$$

Therefore the laminate configuration for the sidewall is six plies as follows: 2 at $0^{\circ}, 2$ at $\pm 45^{\circ}$, and 2 at $90^{\circ}$. Note that this also is not a symmetric laminate with respect to bending.

( $f$ ) Select plies at the other span stations. Examining the loads in table step 4.a, we see that: (1) $N_{c x x}$ is smaller at all the other span stations, and (2) $N_{c x y}$ is maximum at the 60 -in. span station. At this point we can either calculate the number of plies at each of the span sections or calculate the number of plies we need for the maximum $N_{c x y}$ at the 60 in. station and use a uniform laminate through the box beam. Using a uniform laminate simplifies the fabrication procedure but it will increase the weight. Assuming that the weight is not critical, we will calculate the number of $\pm 45^{\circ}$ plies we need at maximum $N_{c x y}$ and use this number throughout the box beam.

The number of \pm 45 plies at maximum $N_{c x y}(60-i n$. station $)$ is

$$
\mathrm{N}_{\ell \pm 45}=\frac{\mathrm{N}_{c x y} E_{\ell 11} / 2 \mathrm{G}_{\theta 12}}{\mathrm{~S}_{\ell 11 \mathrm{C}^{t} \ell}}=\frac{3320 \mathrm{ib} \mathrm{in} \cdot(1 / 2)(18.5 / 5.8)}{180000 \mathrm{~b} / \mathrm{sq} \mathrm{in.} \times 0.005 \mathrm{in.}}=5.8 \approx 6
$$

Therefore, the laminate configuration for the box beam is 10 plies as follows: 4 at $\pm 45^{\circ}, 4$ at $0^{\circ}$, and 2 at $90^{\circ}$. Using the conventional notation, this is expressed:

$$
\left[ \pm 45 / 0_{2} / 90\right]_{S}
$$

(g) Select the minimum number of plies at the various span stations to meet strength requirements. Repeating the calculations in steps $4 . b, 4 . c$, and 4.d for the other span stations and summarizing the results we have the results listed in table 3 .

Remarks:

(1) The maximum number of $0^{\circ}$ plies required is four while that for \pm 45 is six. These ply combinations result in an unsymmetric laminate.

(2) The total number of plies required varies from six in the walls to nine in the covers.

(3) For fabrication convenience, assume constant number of plies throughout the box beam. 
(4) Since the laminate is relatively thin, panel buckling will control the design.

(5) Decide on a laminate configuration and check the panel buckling load.

(6) A reasonable symmetric laminate configuration is the 10-ply laminate, $0.050 \mathrm{in}$. thick, as follows: four plies at $0^{\circ}$, four plies at $\pm 45^{\circ}$, and two plies at $90^{\circ}$ as was already mentioned. Using conventional notation this laminate configuration is designated:

$$
\left[ \pm 45 \% / 0_{2} / 90\right]_{S}
$$

\section{Step 5:}

Calculate the composite stresses at the four-span stations. These stresses are calculated by dividing the in-plane load at that station with the laminate thickness $\left(N_{c x x} / t_{l}\right.$, etc.). Summarizing the results in tabular form, we have the results listed in table 4.

The composite stresses summarized above will be used to check the buckling stresses and the ply stresses as described below.

\section{Step 6:}

Calculate the buckling stresses of the panels at each bay. In order to expedite these calculations, we use the midbay panel dimensions and apply the stresses summarized above. This approach is reasonable for preliminary design. However, it needs to be checked with finite element analys is for more accurate results.

Tabulating the results we have the summary shown in table 5 .

We calculate the buckling stresses by using the approximate interaction equation (ref. 1):

$$
\frac{\sigma_{c x x}}{\sigma_{c x x}^{(c r)}}+\left(\frac{\sigma_{c x y}}{\sigma_{c x y}(c r)}\right)^{2} \leq 1
$$

where

$$
\begin{aligned}
& \sigma_{c x x}^{(c r)} \approx \frac{\pi^{2} t_{c}^{2} E}{12 b^{2}\left(1-v_{c x y^{v} c y x}\right)}\left(\frac{a}{b}+\frac{b}{a}\right)^{2} \\
& \left.\sigma_{c x y}^{(c r)} \approx \frac{7 \pi^{2} t_{c}^{2} E}{12 b^{2}\left(1-v_{c x y}{ }^{v} c y x\right.}\right)\left(1 \leq \frac{a}{b} \leq 2\right) \\
& E=\sqrt[3]{\sqrt{4 E_{c x x^{E}} E_{c y y^{G} c x y}}}
\end{aligned}
$$


The moduli and Poisson's ratios for a $\left[ \pm 45 / 0_{2} / 90\right]_{S}$ AS/E angleplied laminate are (ref. 1):

$$
\begin{gathered}
E_{c x x}=9.6 \mathrm{mpsi} ; E_{c y y}=6.5 \mathrm{mpsi} \\
G_{c x y}=2.3 \mathrm{mpsi} ; v_{c x y}=0.33 ; v_{c y x}=0.22
\end{gathered}
$$

Substituting these values, we calculate

$$
E=3 \sqrt{4 \times 9.6 \times 6.5 \times 2.3} \mathrm{mpsi}=8.31 \mathrm{mps} i
$$

First we check the buckling stresses of the top cover at the first midbay (0 to 20 )

$$
\begin{gathered}
\sigma_{c x x}^{(c r)}=\frac{\pi^{2}(0.05)^{2} \times 8.31 \times 10^{6}}{12(18.4)^{2}(1-0.33 \times 0.22)}\left(\frac{20}{18.4}+\frac{18.4}{20}\right)^{2}=218 p s i \\
\sigma_{c x y}^{(c r)}=\frac{7 \pi^{2}(0.05)^{2} \times 8.31 \times 10^{6}}{12(18.4)^{2}(1-0.33 \times 0.22)}= \pm 380.9 \text { psi }
\end{gathered}
$$

Using these buckling stresses in the combined stress interaction equation above, we calculate:

$$
\begin{gathered}
\frac{-79200}{-218}+\left(\frac{-6700}{-380.9}\right)^{2} \leq 1 \\
672.7>1
\end{gathered}
$$

indicating that the panel will buckle.

Remark: These panel thicknesses are too low to resist buckling due to the applied load stresses in the top cover and back side wall panels since all these panels are subjected to combined compressive and shear stresses. On the other hand, the panels in the bottom cover and front side wall may not buckle because these panels are subjected to combined tensile and shear stresses. The most critical case is the bottom cover at the third midbay ( 40 to 60 ). The calculated individual buckling stresses for this panel are:

$$
\sigma_{c x x}^{(c r)}=714 \text { psi; } \sigma_{c x y}^{(c r)}=942 p s i
$$

and combined in the interaction equation:

$$
\frac{59260}{-714}+\left(\frac{27400}{942}\right)^{2} \leq 1
$$

763 > 1 and this panel will also buckle.

The conclusion from the above calculations is that the panel thickness sized for strength is too thin to resist buckling. 
At this point, we can consider several alternatives to increase the panel buckling resistance. The obvious ones are: (1) increase the panel thickness, (2) reduce the panel edge dimensions by using inner walls and additional bulkheads, and ( 3 ) use combinations of these.

First we check alternative (1) - increase panel thickness. Calculate panel thickness to resist buckling stress. Since the buckling stress varies with the thickness squared and assuming panel thickness in multiples of $\left[ \pm 45 / 0_{2} / 90\right]_{5}$ we calculate a thickness for the compressive stress:

$$
t_{c} \approx\left(\frac{792000}{218}\right)^{1 / 3} 0.36 \text { in.; use } 0.45 \text { in. } \approx 0.50 \mathrm{in.}
$$

for combined stress.

This results in a $\left[ \pm 45 / 0_{2} / 90\right]_{10 S}$ symmetric laminate with 100 plies. This many plies will substantially increase the material and fabrication costs.

Check buckling stresses for the same panel.

$$
\begin{aligned}
\sigma_{C X x}= & (0.05 / 0.50) 79200 p s i=7920 \mathrm{psi} \\
\sigma_{C x y}= & (0.05 / 0.50) 6700 \mathrm{psi}=670 \mathrm{psi} \\
\sigma_{c x x}^{(c r)}= & (0.50 / 0.05)^{2} 218 \mathrm{psi}=21800 \mathrm{psi} \\
\sigma_{c x y}^{(c r)}= & (0.5 / 0.05)^{2} 380.9 \mathrm{psi}=38090 \mathrm{psi} \\
& \frac{\sigma_{c x x}}{\sigma_{c x x}^{(c r)}}+\left(\frac{\sigma_{c x y}}{\sigma_{c x y}^{(c r)}}\right)^{2} \leq 1 \\
\frac{7920}{21800}+ & \left(\frac{670}{38090}\right)^{2}=0.363<1
\end{aligned}
$$

Therefore the panel satisfies the combined stress buckling interaction equation with a margin of safety $1-0.363=0.64$.

Alternative (2) will increase the buckling stresses but will not reduce the stresses due to applied loads. Alternative (3) on the other hand will increase the buckling stresses and also reduce the stresses due to applied loads.

Check buckling stresses by adding an inner vertical wall through the box beam center. Since this will reduce the panel edge dimension by 2 it will increase the buckling stress by 4 . Therefore we assume 60-ply laminate as follows: 


$$
\left[ \pm 45 / 0_{2} / 90\right]_{6 \mathrm{~s}}
$$

with $0.3 \mathrm{in.}$ thickness.

The stresses in the panel at the first bay are:

$$
\begin{aligned}
& \sigma_{c x x}=(0.05 / 0.3) 79200 \text { psi }=13200 \text { psi } \\
& \sigma_{c x y}=(0.05 / 0.3) 6700 \text { psi }=1117 \text { psi }
\end{aligned}
$$

The corresponding buckling stresses are

$$
\begin{aligned}
& \sigma_{c x x}^{(c r)}=4(0.3 / 0.05)^{2} 218 p s i=31392 p s i \\
& \sigma_{c x y}^{(c r)}=4(0.3 / 0.05)^{2} 380.9 p s i=54850 p s i
\end{aligned}
$$

The combined stress buckling interaction equation is

$$
\frac{13200}{31392}+\left(\frac{1117}{54850}\right)^{2}=0.42<1 \quad 0 . K .
$$

and the margin of safety MOS $=0.58$.

This is a lighter weight design (by 30 percent) compared to that of alternative (1).

\section{Step 8: Summarize Design}

The designed box-beam, therefore is a 60-ply $\left[ \pm 45 / 0_{2} / 90\right]_{6 s}$ laminate 0.3 in. thick with an inner vertical wall through the box-beam center. The panel geometry at mid bays and the respective stresses at the bulkheads are summarized in table VI.

Step 9: Check Tip Displacements

(a) Vertical displacement. - This displacement is calculated from (neglecting box beam weight)

$$
\omega=\frac{P_{z} e^{3}}{{ }_{c x x}{ }^{I} \text { cyy }}
$$


where $I_{\text {cyy }}$ is calculated at midspan as follows:

$$
\begin{aligned}
I_{c y y} & =\left[2 b\left(\frac{h}{2}\right)^{2} t_{c}+3\left(\frac{1}{12}\right) h^{3} t_{c}\right] \text { in. }^{4} \\
& =\left[2 \times 15\left(\frac{7.5}{2}\right)^{2}(0.3)+3 \frac{1}{12}(7.5)^{3}(0.3)\right] \text { in. }^{4} . \\
& =(126.6+31.6) \mathrm{in.}^{4} \\
& =158.2 \text { in. }^{4}
\end{aligned}
$$

The values of the variables required in the above equation are

$$
\begin{aligned}
& p_{z}=132001 \mathrm{~b} \\
& \ell=60 \mathrm{in} \text {. } \\
& E_{\text {CXX }}=9.6 \mathrm{mpsi} \\
& I_{\text {cyy }}=158.2 \text { in. }^{4} \\
& w=\frac{132001 \mathrm{~b} \times 60 \times 60 \times 60 \mathrm{in}^{3}}{3 \times 9600000\left(1 \mathrm{~b} / \mathrm{in}^{2}\right) \times 158.2 \mathrm{in}^{4}} \\
& w=0.63 \text { in. }<0.90(1.5 \% 60 \text { in. }) \text { in. } 0 . k \text {. } \\
& \text { MOS }=\frac{0.90}{0.63}-1.0=0.43
\end{aligned}
$$

(b) Lateral displacement. - This displacement is calculated from

$$
v=\frac{P y^{\ell^{3}}}{3 E_{C x{ }^{I} c z z}}
$$

where, again, $I_{c z z}$ is calculated at midspan as follows:

$$
\begin{aligned}
I_{C Z Z} & =\left[2 h\left(\frac{b}{2}\right)^{2} t_{c}+2\left(\frac{1}{12}\right) b^{3} t_{c}\right] \text { in. } \\
& =\left[2(7.5)\left(\frac{15}{2}\right)^{2}(0.3)+2\left(\frac{1}{12}\right)(15)^{3}(0.3)\right] \text { in. }^{4} \\
& =[253.1+168.8] \text { in. } 4 \\
& =421.9 \text { in. }^{4}
\end{aligned}
$$


The values of the variables required to calculate the lateral displacement are

$$
\begin{aligned}
P_{y} & =6600 \mathrm{lb} \\
\ell & =60 \mathrm{in} . \\
E_{C X x} & =9.6 \mathrm{mpsi} \\
I_{C Z z} & =421.9 \mathrm{in}^{4} \\
v & =\frac{6600 \mathrm{lb} \times 60 \times 60 \times 60 \mathrm{in}^{3}}{3 \times 9600000\left(1 \mathrm{~b} / \mathrm{in}^{2}\right) \times 421.9 \mathrm{in} .^{4}} \\
v & =0.12 \mathrm{in} .<0.90 \mathrm{in} .0 . \mathrm{K} . \\
& \text { MOS }=\frac{0.90}{0.12}-1=6.5
\end{aligned}
$$

(c) Angle of Twist. - This angle is calculated from

$$
\theta \approx \frac{M_{x} \ell}{J G}
$$

where

$J=I_{\text {cxx }}+I_{\text {cyy }}$

and

$G=G_{c x z}=G_{c x y}$

The values of the variables required to calculate the twist angle are

$$
\begin{aligned}
M_{X} & =200000 \mathrm{in.}-1 \mathrm{~b} \\
\ell & =60 \mathrm{in} . \\
J & =(158.2+421.9) \mathrm{in}^{4}=580.1 \mathrm{in.}^{4} \\
G & =2.3 \mathrm{mpsi} \\
\theta & =\frac{200000 \mathrm{in.}-1 \mathrm{~b} \times 60 \mathrm{in} .}{580.1 \mathrm{in.}^{4} \times 2300000 \mathrm{ib} / \mathrm{in}^{2}} \mathrm{rad} \\
& =0.008994 \mathrm{rad} \\
\theta & =0.52^{\circ}<1.0^{\circ} \quad 0 . \mathrm{K} . \\
& \text { MOS }=\frac{1.0}{0.52}-1=0.92
\end{aligned}
$$


Step 10:

Calculate the first flap-wise, edge-wise frequencies, and the first torsional frequency.

(a) The flap-wise (vertical) frequency is calculated from

$$
\omega_{z} \approx \frac{1}{2 \pi}\left(\frac{1.9}{\ell}\right)^{2}\left[\frac{E_{c x x} I_{c x x}}{M}\right]^{1 / 2} c y c / s e c
$$

where $M$ is the mass per unit length and $I_{c x x}$ is the moment of inertia, both calculated at midspan (2-covers, 3-walls and 4-bulkheads)

$$
\begin{aligned}
& M=\left[2 b+3 h+\frac{1}{l} \sum_{i=1}^{4}(b \times h)_{i}\right]{ }^{t_{c} \rho / g}=\left[30+22.5+\frac{1}{60}(478)\right] \frac{0.3 \times 0.06}{386.4} 1 b / \sec ^{2} \\
& =0.0028 \frac{1 \mathrm{~b} \sec ^{2}}{\text { in. }} \frac{1}{\text { in. }}
\end{aligned}
$$

The values of the variables required to calculate this frequency are

$$
\begin{aligned}
& \ell=60 \text { in. } \\
& E_{C X X}=9.6 \mathrm{mpsi} \\
& I_{C X X}=158.2 \text { in. }^{4} \\
& M=0.0028 \frac{1 \mathrm{~b} \sec ^{2}}{\text { in. }} \frac{1}{i n .} \\
& \omega_{z}=\frac{(1.9 \times 1.9)}{2 \pi(60 \text { in. } \times 60 \text { in. })}\left[\frac{9600000\left(1 \mathrm{~b} / \mathrm{in}^{2}\right) 158.2 \mathrm{in.}^{4}}{0.0028 \frac{1 \mathrm{~b} / \mathrm{sec}^{2}}{\text { in. }} \frac{1}{\mathrm{in.}}}\right]^{1 / 2} \mathrm{cyc} / \mathrm{sec} \\
& \omega_{z}=117.5 \mathrm{cyc} / \mathrm{sec}>100 \mathrm{cyc} / \mathrm{sec} \text { O.K. } \\
& \text { MOS }=\frac{117.7}{100}-1=0.18
\end{aligned}
$$

(b) The edge-wise lateral frequency is calculated from

$$
\omega_{y}=\frac{1}{2 \pi}\left(\frac{1.9}{P}\right)^{2}\left[\frac{E_{c x x} I_{c y y}}{M}\right]^{1 / 2}
$$

This equation differs from $\omega_{z}$ only in $I_{c y y}$. We can expedite the calculation. 


$$
\begin{aligned}
\omega_{y} & \approx\left(\frac{I_{\text {cyy }}}{I_{\text {cxx }}}\right)^{1 / 2} \omega_{z} \\
& \approx\left(\frac{421.9}{158.2}\right)^{1 / 2} \times 117.5 \mathrm{cyc} / \mathrm{sec}
\end{aligned}
$$

$\omega_{y} \approx 191.9 \mathrm{cyc} / \mathrm{sec}>500 \mathrm{cyc} / \mathrm{sec} \quad 0 . K$.

$\operatorname{MOS}=\frac{191.9}{150}-1=0.23$

(c) The torsional frequency is calculated from

$$
\omega_{t} \approx \frac{1}{4 l}\left(\frac{G g}{\rho}\right)^{1 / 2}
$$

The values for the variables are

$$
\begin{aligned}
& \ell=60 \mathrm{in} . \\
& G=2.3 \mathrm{mpsi} \\
& g=386.4 \mathrm{in} / \mathrm{sec}^{2} \\
& \rho=0.06 \mathrm{lb} / \mathrm{in}^{3}
\end{aligned}
$$

$$
\begin{gathered}
\omega_{t} \approx \frac{1.0}{4 \times 60}\left[\frac{2300000\left(1 \mathrm{~b} / \mathrm{in}^{2}\right) \times 386.4 \mathrm{in} . / \mathrm{sec}^{2}}{0.06 \mathrm{lb} / \mathrm{in} .^{3}}\right]^{1 / 2} \\
\omega_{t} \approx 507.1 \mathrm{cyc} / \mathrm{sec}>450 \mathrm{cyc} / \mathrm{sec} \quad 0 . \mathrm{K} . \\
\operatorname{MOS}=\frac{507.1}{450}-1=0.13
\end{gathered}
$$

Step 11: Check Local Panel Vibration

We calculate the first frequency for the first bay panel (0-20 span) assuming a rectangular panel with midside dimensions. This frequency is given by

$$
\begin{aligned}
& \omega=\frac{\pi t_{c}}{2 a^{2}}\left(\frac{g}{12 p\left(1-v_{c x y}{ }^{v_{c y x}}\right)}\right)^{1 / 2}\left[\left(1+2 v_{c y x} c^{2}\right) E_{c x x}+E_{c y y} c^{4}\right. \\
& \left.+4 C^{2}\left(1-v_{c x y}{ }^{v} c y x\right){ }_{c x y}\right]^{1 / 2}
\end{aligned}
$$


where

$t_{c}$ panel thickness (in.)

a panel x-edge dimension (in.)

g gravity acceleration (in. $/ \sec ^{2}$ )

$\rho$ composite laminate density (lb/in. ${ }^{3}$ )

C $a / b$ where $b$ is the panel y-edge dimension (in.)

where $E_{C x x}, E_{C y y}$, and $G_{C x y}$ are the composite laminate moduli and where $u_{c x y}$ and $v_{\text {cyx }}$ are composite laminate Poisson's ratios.

The values for the variables in the frequency calculation are

$$
\begin{array}{ll}
t_{c}=0.3 \mathrm{in} . & E_{c x x}=9.6 \mathrm{mpsi} \\
a=20 \mathrm{in} . & E_{c y y}=6.5 \mathrm{mpsi} \\
g=386.4 \mathrm{in} . / \mathrm{sec}^{2} & G_{c x y}=2.3 \mathrm{mpsi} \\
p=0.06 \mathrm{lb} / \mathrm{in.} .^{3} & v_{c x y}=0.33 \\
c=(20 / 9.2)=2.17 & v_{c y x}=0.22
\end{array}
$$

Substituting these values in the frequency equation

$$
\begin{gathered}
\omega=\frac{\pi(0.3)}{2 \times 20 \times 20}\left[\frac{386.4}{12 \times 0.06(1-0.33 \times 0.22)}\right]^{1 / 2}\left[\left(1+2 \times 0.22 \times 2.17^{2}\right) \times 9.6\right. \\
\left.+4(2.17)^{2}(1-0.33 \times 0.22) \times 2.3+6.5 \times(2.17)^{4}\right]^{1 / 2} \times 1000 \mathrm{cyc} / \mathrm{sec} \\
\omega=414.4 \mathrm{cyc} / \mathrm{sec}
\end{gathered}
$$

This frequency is greater than the first two $\left(\omega_{z}\right.$ and $\left.\omega_{y}\right)$ frequencies of the box beam. Therefore, no local vibration will occur prior to the first box beam modes. However it could occur prior to the first torsional mode.

\section{Step 12: Check Ply Stresses}

The ply stresses are determined through the use of the ply stress influence coefficients as described in detail in Ref. 1. The ply stress influence coefficient for the laminate selected are shown in table VII.

The ply stress $\sigma_{Q 11}$ is calculated as follows (include only nonzero coefficients)

$$
\sigma_{\ell 11}=1.98 \sigma_{C x x}-0.56 \sigma_{C y y}+9.35 \Delta T+627 \mathrm{M}
$$


Examining the ply stress influence coefficients we see that $\sigma_{\ell} 11$ for the $+45^{\circ}$ and $\sigma_{\ell 22}$ for the $-45^{\circ}$ ply have relatively large values. From the panel composite stresses summary in step 8 we check the bottom cover in the bays 2 and 3 as follows: (neglecting temperature and moisture).

(a) $+45^{\circ}-$ Ply (3-bay bottom cover)

$$
\begin{aligned}
\sigma_{\ell 11}= & 0.70 \sigma_{C x x}+4.0 \sigma_{C x y} \\
= & 0.70 \times 9877+4.0 \times 4567 \\
= & 25182 \mathrm{psi} \quad 220000 \mathrm{psi} \quad 0 . K . \\
& \quad \operatorname{MOS}=\frac{220000}{25182}-1=7.74
\end{aligned}
$$

(b) $-45^{\circ}-$ Ply (1-bay bottom cover)

$$
\begin{aligned}
\sigma_{l 22}= & 0.55 \sigma_{C x x}+0.19 \sigma_{C x y} \\
= & 0.55 \times 13200+0.19 \times 2217 \\
= & 7681 \mathrm{psi}<8000 \mathrm{psi} 0 . K . \\
& \quad \text { MOS }=\frac{8000}{7681}-1=0.04
\end{aligned}
$$

(c) Check the above ply stresses by including residual and moisture stresses. For residual stresses $\Delta T=-300^{\circ} \mathrm{F}$ which is the difference between the cure and room temperatures. For the moisture stresses assume $M=1$ percent by weight.

$+45^{\circ}-P 1 y:$

$$
\begin{aligned}
\sigma_{Q 11}= & 0.70 \sigma_{C X X}+4.00 \sigma_{C X y}+21.02 \Delta T+1413 \mathrm{M} \\
= & 0.70 \times 9877+4.0 \times 4567+21.02(-300)+1413(1) \\
= & 6914+18268-6306+1413 \\
= & 20289 \mathrm{psi}<220000 \text { psi } 0 . K . \\
& \quad M O S=\frac{220000}{20289}-1=9.8
\end{aligned}
$$

$-45^{\circ}-\mathrm{Pl} y:$

$$
\begin{aligned}
\sigma_{\ell 22} & =0.55 \sigma_{C X X}+0.19 \sigma_{C x y}-1876 \Delta T-1263 \mathrm{M} \\
& =0.55 \times 13200+0.19 \times 2217-18.76(-300)-1263(1) \\
& =7620+421+5628-1263 \\
& =12046 \text { psi }>8000 \text { psi N.G. }
\end{aligned}
$$




$$
\text { MOS }=\frac{8000}{12046}-1=-0.34
$$

This last calculation indicates that the $-45^{\circ}-P l y$ will crack in transverse tension due to combined design mechanical and environmental loads. The last calculation also illustrates the significance of residual stresses in composites. Since this is a matrix failure mode, we check the ply stress at specified mechanical loads. Recall that the design loads are two times the specified loads.

$$
\begin{aligned}
\sigma_{\ell 22} & =\frac{1}{2}(7620+421)+5628-1263 \\
& =8386 \mathrm{ps} \mathbf{i}>8000 \mathrm{psi} \\
\text { MOS } & =\frac{8000}{8386}-1=-0.05
\end{aligned}
$$

This may be considered acceptable in the absence of cyclic loads.

\section{Step 13: Summarize Design Results}

(a) Laminate configuration $\left[ \pm 45 / 0_{2} / 90\right] 6 s$ s 0.3 in. thick

(b) Box-beam design - uniform laminate thickness, two intermediate bulkheads, and one inner wall located at the box beam center (see fig. 2)

(c) Box-beam weight $=66 \mathrm{lb}$ (composite volume times density)

(d) Tip displacements MOS

Displacement MOS

$\begin{array}{ll}w & 0.43 \\ v & 6.50 \\ \theta & 0.92\end{array}$

(e) Buckling load MOS $=0.58$

(f) Vibration frequencies MOS

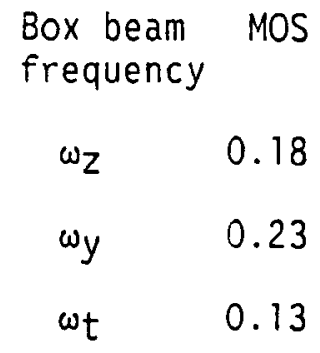


Pane1 1-bay

top cover 1.16

(g) Ply stresses

$+45^{\circ}$-Ply (3-bay-bottom cover)

longitudinal stress

mechanical loads

MOS

mechanical and environmental 9.8

$-45^{\circ}$-Ply (1-bay-bottom cover)

transverse stress

mechanical loads 0.04

mechanical and environmental -0.34

\section{CONCLUDING REMARKS}

Step-by-step design procedures are described which can be used for the preliminary design of composite box beams. The various calculations in these procedures are arranged so that they can be performed using a pocket calculator. The sample calculations are for the design of a cantilevered composite box beam subjected to end loads. The composite laminate is selected to satisfy design requirements for local buckling, tip displacements, beam and panel vibrations, and ply stresses including thermal and hygral (moisture) stresses. The procedures and the sample calculations illustrated can be used for the preliminary design of composite built-up structures in general.

\section{REFERENCES}

1. Chamis, C.C.: Design Procedures for Fiber Composite Structural Components: Panels Subjected to Combined In-Plane Loads. Proceedings of the 40th Annual SPI Conference, Society of the Plastics Industry, paper 15-B, 1985, pp. 1-11. (NASA TM-86909) 
TABLE 1. - TYPICAL PROPERTIES OF UNIDIRECTIONAL COMPOSITES AT ROOM TEMPERATURE

\begin{tabular}{|c|c|c|c|c|c|c|c|c|c|c|}
\hline Properties & Symbol & Units & $\begin{array}{l}\text { Boronl } \\
\text { epoxy }\end{array}$ & $\begin{array}{l}\text { Boron } 1 \\
\text { poly } \\
\text { mide }\end{array}$ & $\begin{array}{l}\text { S-glass } \\
\text { /epoxy }\end{array}$ & $\begin{array}{c}\text { Modmor II } \\
\text { epoxy }\end{array}$ & $\begin{array}{l}\text { Modmor I/ } \\
\text { polymide }\end{array}$ & $\begin{array}{c}\text { Thorne } 1 \\
300 / \\
\text { epoxy }\end{array}$ & $\begin{array}{c}\text { Kevlar } \\
49 / \\
\text { epoxy }\end{array}$ & $\begin{array}{l}\text { Graphite } \\
\text { AS/epoxy }\end{array}$ \\
\hline Fiber volume ratio & $k_{f}$ & ------ & 0.50 & 0.49 & 0.72 & 0.45 & 0.45 & 0.70 & 0.54 & 0.60 \\
\hline Density & $\boldsymbol{P}_{\mathbf{l}}$ & $10 /$ in $^{3}$ & 0.073 & 0.072 & 0.077 & 0.056 & 0.056 & 0.058 & 0.049 & 0.057 \\
\hline $\begin{array}{l}\text { Longitudinal thermal } \\
\text { coefficient }\end{array}$ & $a_{\ell 11}$ & $\log ^{-6}$ in & 3.4 & 2.7 & 2.1 & $-\infty-\infty$ & 0.0 & 0.01 & -1.60 & 0.40 \\
\hline $\begin{array}{l}\text { Transverse thermal } \\
\text { coefficient }\end{array}$ & $a_{122}$ & $\begin{array}{l}10^{-6} \text { in } \\
\operatorname{lin} /\end{array}$ & 16.9 & 15.8 & 9.3 & 18.5 & 14.1 & 12.5 & 31.3 & 16.4 \\
\hline Longltudinal modulus & $E_{l 11}$ & $10^{6}$ psi & 29.2 & 32.1 & 8.8 & 27.5 & 31.3 & 21.0 & 12.2 & 16.0 \\
\hline Transverse modulus & $E_{\ell 22}$ & $10^{6}$ psi & 3.15 & 2.1 & 3.6 & 1.03 & 0.72 & 1.5 & 0.70 & 2.2 \\
\hline Shear modulus & $G_{l 12}$ & $10^{6} \mathrm{psi}$ & 0.78 & 1.11 & 1.74 & 0.9 & 0.65 & 1.0 & 0.41 & 0.72 \\
\hline Major Poissons's ratio & $v_{\ell} 12$ & ----- & 0.17 & 0.16 & 0.23 & 0.10 & 0.25 & 0.28 & 0.32 & 0.25 \\
\hline Minor Poissons's ratio & $v_{221}$ & ------- & 0.02 & 0.02 & 0.09 & ------ & 0.02 & 0.01 & 0.02 & 0.34 \\
\hline $\begin{array}{l}\text { Longitudinal tensile } \\
\text { strength }\end{array}$ & $S_{111 T}$ & psi & 199000 & 151000 & 187000 & 122000 & 117000 & 218000 & 172000 & 220000 \\
\hline $\begin{array}{l}\text { Longitudinal compres- } \\
\text { sive strength }\end{array}$ & $S_{111 C}$ & psi & 232000 & 158000 & 119000 & 128000 & 94500 & 247000 & 42000 & 180000 \\
\hline $\begin{array}{l}\text { Transverse tensile } \\
\text { strength }\end{array}$ & $S_{l 22 T}$ & psi & 8100 & 1600 & 6670 & 6070 & 2150 & 5850 & 1600 & 8000 \\
\hline $\begin{array}{l}\text { Transverse compres- } \\
\text { sive strength }\end{array}$ & $S_{l 22 C}$ & psi & 17900 & 9100 & 23500 & 28500 & 10200 & 35700 & 9400 & 36000 \\
\hline $\begin{array}{l}\text { Intralaminar shear } \\
\text { strength }\end{array}$ & $S_{212 S}$ & psi & 9100 & 3750 & 6500 & 8900 & 3150 & 9800 & 4000 & 10000 \\
\hline $\begin{array}{l}\text { Longitudinal molsture } \\
\text { coefficient }\end{array}$ & $B_{\ell 11}$ & $10^{-2}$ in & 0.003 & 0.003 & 0.014 & 0.003 & 0.003 & 0.006 & 0.008 & 0.006 \\
\hline $\begin{array}{l}\text { Transverse moisture } \\
\text { coefficient }\end{array}$ & $B_{\ell 22}$ & $10^{-2}$ in & 0.168 & 0.168 & 0.128 & 0.129 & 0.129 & 0.129 & 0.151 & 0.129 \\
\hline $\begin{array}{l}\text { Glass transition } \\
\text { temperature } \\
\text { (estimate) }\end{array}$ & $T_{G D}$ & 'F & 420 & 700 & 420 & 420 & 700 & 420 & 420 & 420 \\
\hline
\end{tabular}

TABLE II. - FORCES IN COVERS AND SIDEWALLS

\begin{tabular}{|c|c|c|c|c|c|c|c|c|c|c|c|c|c|}
\hline \multirow{2}{*}{$\begin{array}{c}\text { Span } \\
\text { station, } \\
\text { in. }\end{array}$} & \multirow{2}{*}{$\begin{array}{c}\text { Length, } \\
\text { in. }\end{array}$} & \multicolumn{6}{|c|}{ Covers } & \multicolumn{6}{|c|}{ Side Walls } \\
\hline & & $\begin{array}{l}\text { Depth, } \\
\text { in. }\end{array}$ & $\begin{array}{l}\text { Width, } \\
\text { in. }\end{array}$ & \multicolumn{2}{|c|}{$N_{c x x}, k i s$} & \multicolumn{2}{|c|}{$N_{\text {cxy }}$, kis } & $\begin{array}{l}\text { Depth, } \\
\text { in. }\end{array}$ & $\begin{array}{l}\text { Width, } \\
\text { in. }\end{array}$ & \multicolumn{2}{|c|}{$N_{\text {cyy }}, k i s$} & \multicolumn{2}{|c|}{$M_{c \times z}, k i s$} \\
\hline $\begin{array}{lr}\text { 1. } & 0 \\
\text { 2. } & 20 \\
\text { 3. } & 40 \\
\text { 4. } & 60\end{array}$ & $\begin{array}{r}60 \\
40 \\
20 \\
0\end{array}$ & $\begin{array}{l}10 \\
8.3 \\
6.7 \\
5\end{array}$ & $\begin{array}{l}20 \\
16.7 \\
13.3 \\
10\end{array}$ & $\begin{array}{l}-3960 \\
-3809 \\
-2963 \\
\end{array}$ & $\begin{array}{l}3960 \\
3809 \\
2963 \\
----\end{array}$ & $\begin{array}{r}-335 \\
-523 \\
-874 \\
-2330\end{array}$ & $\begin{array}{r}665 \\
920 \\
1370 \\
+2330\end{array}$ & $\begin{array}{l}20 \\
16.7 \\
13.3 \\
10\end{array}$ & $\begin{array}{l}10 \\
8.3 \\
6.7 \\
5\end{array}$ & $\begin{array}{l}1980 \\
1904 \\
1481 \\
----\end{array}$ & $\begin{array}{l}-1980 \\
-1904 \\
-1481 \\
- \\
--\end{array}$ & $\begin{array}{c}160 \\
74 \\
-137 \\
-3320\end{array}$ & $\begin{array}{l}1160 \\
1516 \\
2107 \\
3320\end{array}$ \\
\hline
\end{tabular}


TABLE III. - PLIES IN COVERS AND SIDEWALLS

\begin{tabular}{|c|c|c|c|c|c|c|c|c|}
\hline \multirow{2}{*}{$\begin{array}{l}\text { Span } \\
\text { station }\end{array}$} & \multicolumn{4}{|c|}{ Plies in the covers } & \multicolumn{4}{|c|}{ Plies in the walls } \\
\hline & $0^{\circ}$ & $\pm 45^{\circ}$ & $90^{\circ}$ & Total & $0^{\circ}$ & $\pm 45^{\circ}$ & $90^{\circ}$ & Total \\
\hline $\begin{array}{lr}\text { 1. } & 0 \\
\text { 2. } & 20 \\
\text { 3. } & 40 \\
\text { 4. } & 60\end{array}$ & $\begin{array}{l}4 \\
4 \\
3 \\
-\end{array}$ & $\begin{array}{l}2 \\
2 \\
4 \\
4\end{array}$ & $\begin{array}{l}2 \\
2 \\
2 \\
-\end{array}$ & $\begin{array}{l}8 \\
8 \\
9 \\
4\end{array}$ & $\begin{array}{l}2 \\
2 \\
2 \\
-\end{array}$ & $\begin{array}{l}2 \\
2 \\
4 \\
6\end{array}$ & $\begin{array}{l}2 \\
2 \\
2 \\
-\end{array}$ & $\begin{array}{l}6 \\
6 \\
8 \\
6\end{array}$ \\
\hline
\end{tabular}

TABLE IV. - PLY STRESSES IN COVERS AND WALLS

\begin{tabular}{|c|c|c|c|c|c|c|c|c|}
\hline \multirow{3}{*}{$\begin{array}{l}\text { Span } \\
\text { station }\end{array}$} & \multicolumn{4}{|c|}{ Covers (psi) } & \multicolumn{4}{|c|}{ Side walls (psi) } \\
\hline & \multicolumn{2}{|c|}{ Top } & \multicolumn{2}{|c|}{ Bottom } & \multicolumn{2}{|c|}{ Front } & \multicolumn{2}{|c|}{ Back } \\
\hline & $\sigma_{c x x}$ & $\sigma_{\text {cxy }}$ & $\sigma_{c x x}$ & $\sigma_{c x y}$ & $\sigma_{\mathrm{cxx}}$ & $\sigma_{c x z}$ & $\sigma_{c x x}$ & $\sigma_{c \times z}$ \\
\hline $\begin{array}{lr}\text { 1. } & 0 \\
\text { 2. } & 20 \\
\text { 3. } & 40 \\
\text { 4. } & 60\end{array}$ & $\begin{array}{ll}-79 & 200 \\
-76 & 180 \\
-59 & 260 \\
\end{array}$ & $\begin{array}{r}-6700 \\
-10460 \\
-17480 \\
46600\end{array}$ & $\begin{array}{ll}79 & 200 \\
76 & 180 \\
59 & 260 \\
-\end{array}$ & $\begin{array}{ll}13 & 300 \\
18 & 400 \\
27 & 400 \\
46 & 600\end{array}$ & $\begin{array}{ll}39 & 600 \\
38 & 080 \\
29 & 600\end{array}$ & $\begin{array}{r}3200 \\
1480 \\
-2740 \\
-66400\end{array}$ & $\begin{array}{ll}-39 & 600 \\
-38 & 080 \\
-29 & 600\end{array}$ & $\begin{array}{ll}23 & 200 \\
30 & 320 \\
42 & 140 \\
66 & 400\end{array}$ \\
\hline
\end{tabular}

TABLE V. - BUCKLING STRESSES

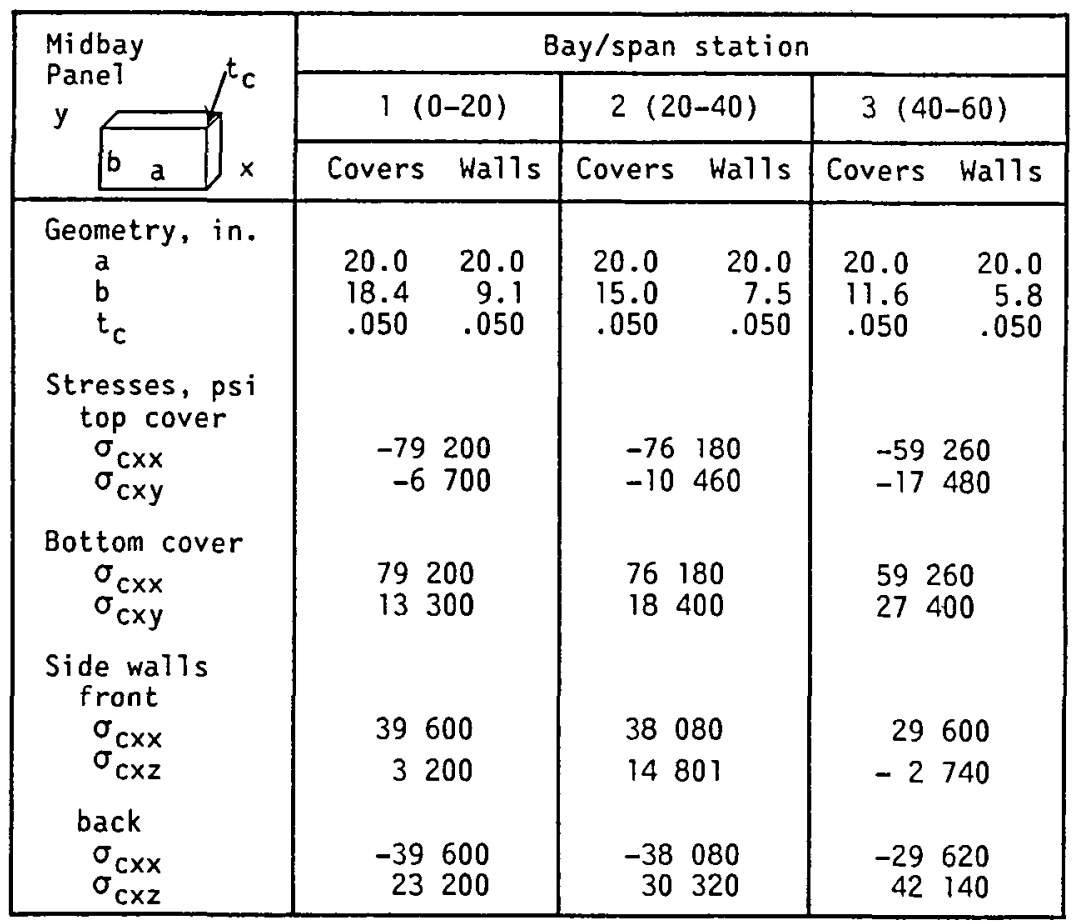


TABLE VI. - FINAL DESIGN STRESSES

\begin{tabular}{|c|c|c|c|c|c|c|c|}
\hline \multirow{3}{*}{$\begin{array}{l}\text { Midbay } \\
\text { Panel }\end{array}$} & \multicolumn{7}{|c|}{ Bay/span station } \\
\hline & & \multicolumn{2}{|c|}{$1(0-20)$} & \multicolumn{2}{|c|}{$2(20-40)$} & \multicolumn{2}{|c|}{$3(40-60)$} \\
\hline & & Covers & Walls & Covers & Walls & Covers & Wal1s \\
\hline \multirow{2}{*}{$\begin{array}{l}\text { Geometry, } \\
\text { in. } \\
a \\
b \\
t_{c} \\
\text { Stresses, psi } \\
\text { Top cover }\end{array}$} & & $\begin{array}{r}20 \\
9.2 \\
0.3\end{array}$ & $\begin{array}{r}20 \\
4.6 \\
0.3\end{array}$ & $\begin{array}{r}20 \\
7.5 \\
0.3\end{array}$ & $\begin{array}{r}20 \\
3.8 \\
0.3\end{array}$ & $\begin{array}{r}20 \\
5.8 \\
0.3\end{array}$ & $\begin{array}{r}20 \\
2.9 \\
0.3\end{array}$ \\
\hline & $\begin{array}{l}\sigma_{\text {cxx }} \\
\sigma_{\text {cxy }}\end{array}$ & & $\begin{array}{l}-13200 \\
-\quad 1167\end{array}$ & & $\begin{array}{l}-12697 \\
-17433\end{array}$ & & $\begin{array}{l}-9877 \\
-2913\end{array}$ \\
\hline Bottom cover & $\begin{array}{l}\sigma_{\mathrm{cxx}} \\
\sigma_{\mathrm{cxy}}\end{array}$ & & $\begin{array}{r}13200 \\
2217\end{array}$ & & $\begin{array}{r}12697 \\
3067\end{array}$ & & $\begin{array}{l}9877 \\
4567\end{array}$ \\
\hline $\begin{array}{l}\text { Walls } \\
\text { front }\end{array}$ & $\begin{array}{l}\sigma_{\mathrm{cxx}} \\
\sigma_{\mathrm{cxz}}\end{array}$ & & $\begin{array}{l}6600 \\
-200\end{array}$ & & $\begin{array}{r}6347 \\
-\quad 938\end{array}$ & & $\begin{array}{r}4933 \\
-2274\end{array}$ \\
\hline back & $\begin{array}{l}\sigma_{c x x} \\
\sigma_{c x z}\end{array}$ & & $\begin{array}{r}-6600 \\
3133\end{array}$ & & $\begin{array}{r}-6347 \\
1161\end{array}$ & & $\begin{array}{r}-4933 \\
5240\end{array}$ \\
\hline inner & $\begin{array}{l}\sigma_{C X X} \\
\sigma_{C X z}\end{array}$ & & $\overline{1467}$ & & $--\overline{1767}$ & & 2189 \\
\hline
\end{tabular}

TABLE VII. - COMBINED HYGROTHERMOMECHANICAL LOAD STRESS ASSESSMEMT

\begin{tabular}{|c|c|c|c|c|c|}
\hline \multirow{3}{*}{$\begin{array}{l}\text { Ply/ply } \\
\text { stress }\end{array}$} & \multicolumn{5}{|c|}{ Ply Stress Influence Coefficients } \\
\hline & \multicolumn{3}{|c|}{$\begin{array}{c}\text { Per unit } \\
\text { composite stress }\end{array}$} & \multirow{2}{*}{$\begin{array}{l}\text { Per unit } \\
\text { composite } \\
\text { temperature, } \\
\left({ }^{\circ} \mathrm{F}\right)\end{array}$} & \multirow[t]{2}{*}{$\begin{array}{c}\text { Per unit } \\
\text { composite moisture, } \\
\text { (1 percent by weight) }\end{array}$} \\
\hline & $\sigma_{c x x}$ & $\sigma_{\text {cyy }}$ & $\sigma_{c x y}$ & & \\
\hline $\begin{array}{l}0^{\circ} \mathrm{ply} \\
\sigma_{\ell 11} \\
\sigma_{\ell 22} \\
\sigma_{\ell 12}\end{array}$ & $\begin{array}{c}1.98 \\
-0.06 \\
0\end{array}$ & $\begin{array}{r}-0.56 \\
0^{18}\end{array}$ & $\begin{array}{r}0 \\
0 \\
0.27\end{array}$ & $\begin{array}{r}9.35 \\
-18.26 \\
0\end{array}$ & $\begin{array}{c}627 \\
-1227 \\
0\end{array}$ \\
\hline $\begin{array}{c}+45^{\circ}-p 1 y \\
\sigma_{\ell 11} \\
\sigma_{\ell 22} \\
\sigma_{\ell 12}\end{array}$ & $\begin{array}{r}0.70 \\
0.55 \\
-0.09\end{array}$ & $\begin{array}{l}1.25 \\
0.10 \\
0.12\end{array}$ & $\begin{array}{c}4.00 \\
-0.19 \\
0\end{array}$ & $\begin{array}{r}21.02 \\
-18.76 \\
0.75\end{array}$ & $\begin{array}{r}1413 \\
-1263 \\
53\end{array}$ \\
\hline $\begin{array}{c}90^{\circ}-p 1 y \\
\sigma_{\ell 11} \\
\sigma_{\ell 22} \\
\sigma_{\ell 12}\end{array}$ & $\begin{array}{c}-0.57 \\
0.12 \\
0\end{array}$ & $\begin{array}{l}3.05 \\
0.01 \\
0\end{array}$ & $\begin{array}{c}0 \\
0 \\
-0.27\end{array}$ & $\begin{array}{c}32.69 \\
-19.37 \\
0\end{array}$ & $\begin{array}{r}2198 \\
-1298 \\
0\end{array}$ \\
\hline
\end{tabular}




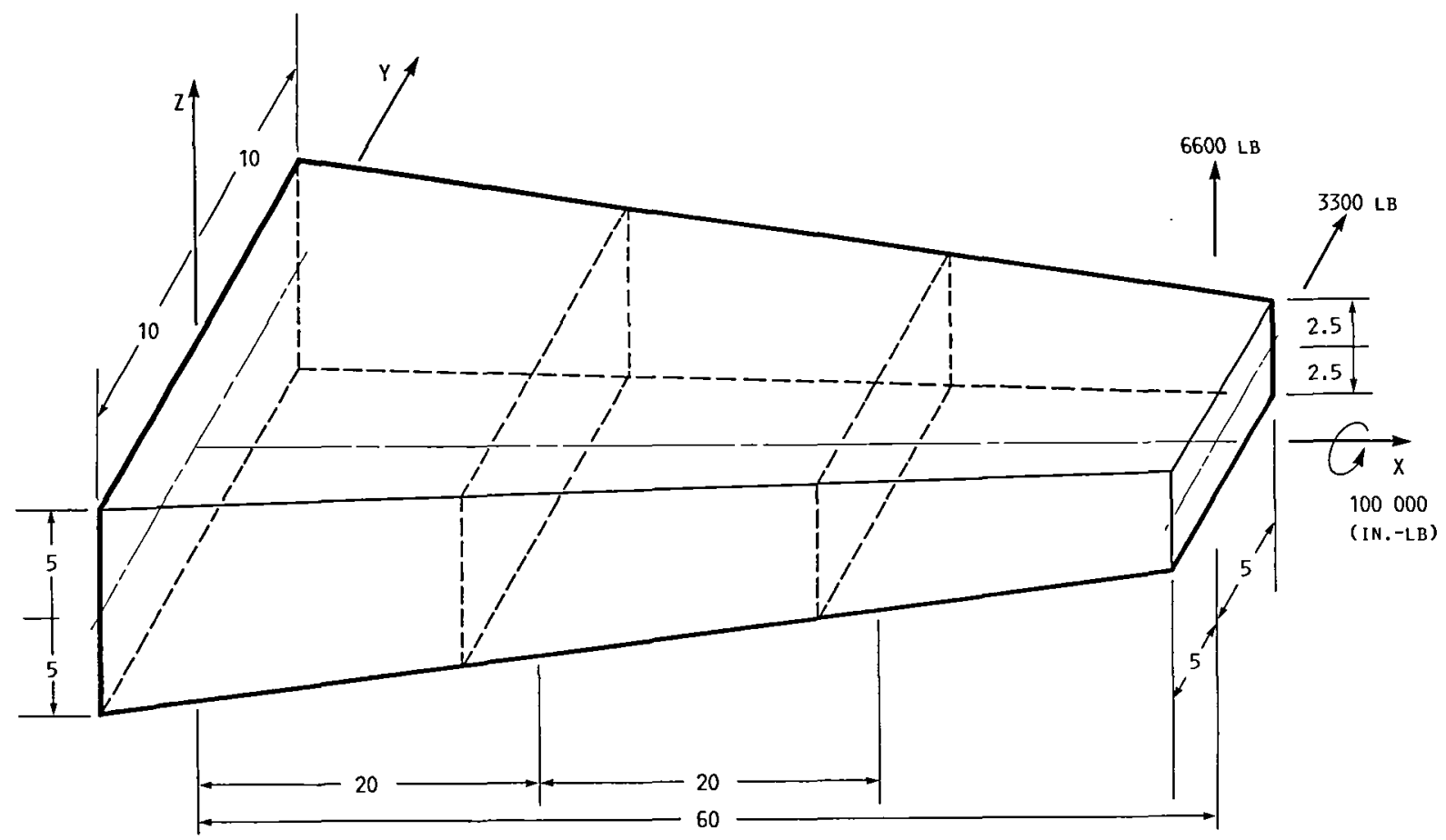

FIGURE 1. - COMPOSITE BOX BEAM GEOMETRY AND SPECIFIED LOADING CONDITIONS (ALL DIMENSIONS IN INCHES: LOADS IN POUNDS: TWIST MOMENT IN INCH-POUNDS).

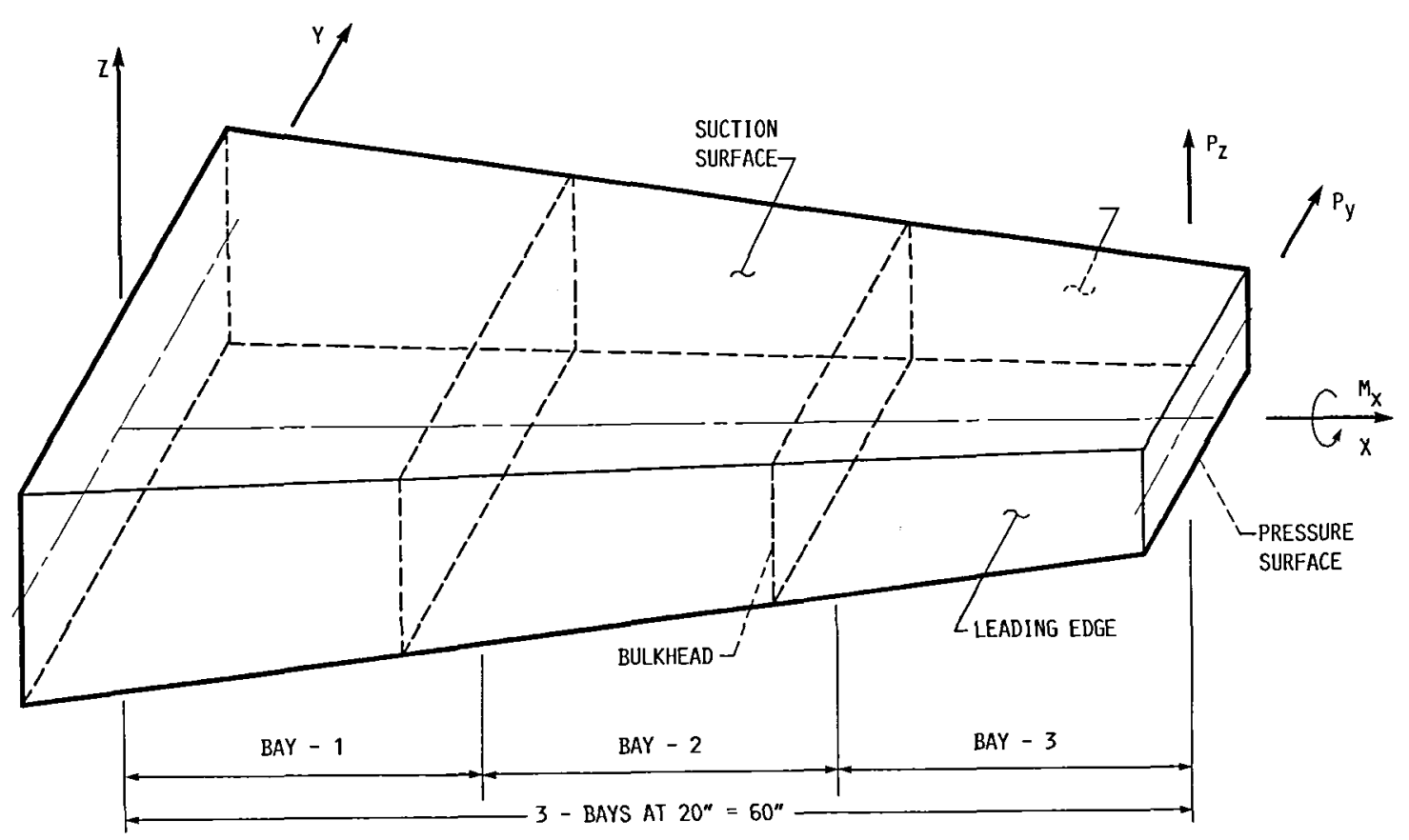

FIGURE 2, - COMPOSITE BOX BEAM SURFACE AND DESIGN LOAD NOMENCLATURE. 


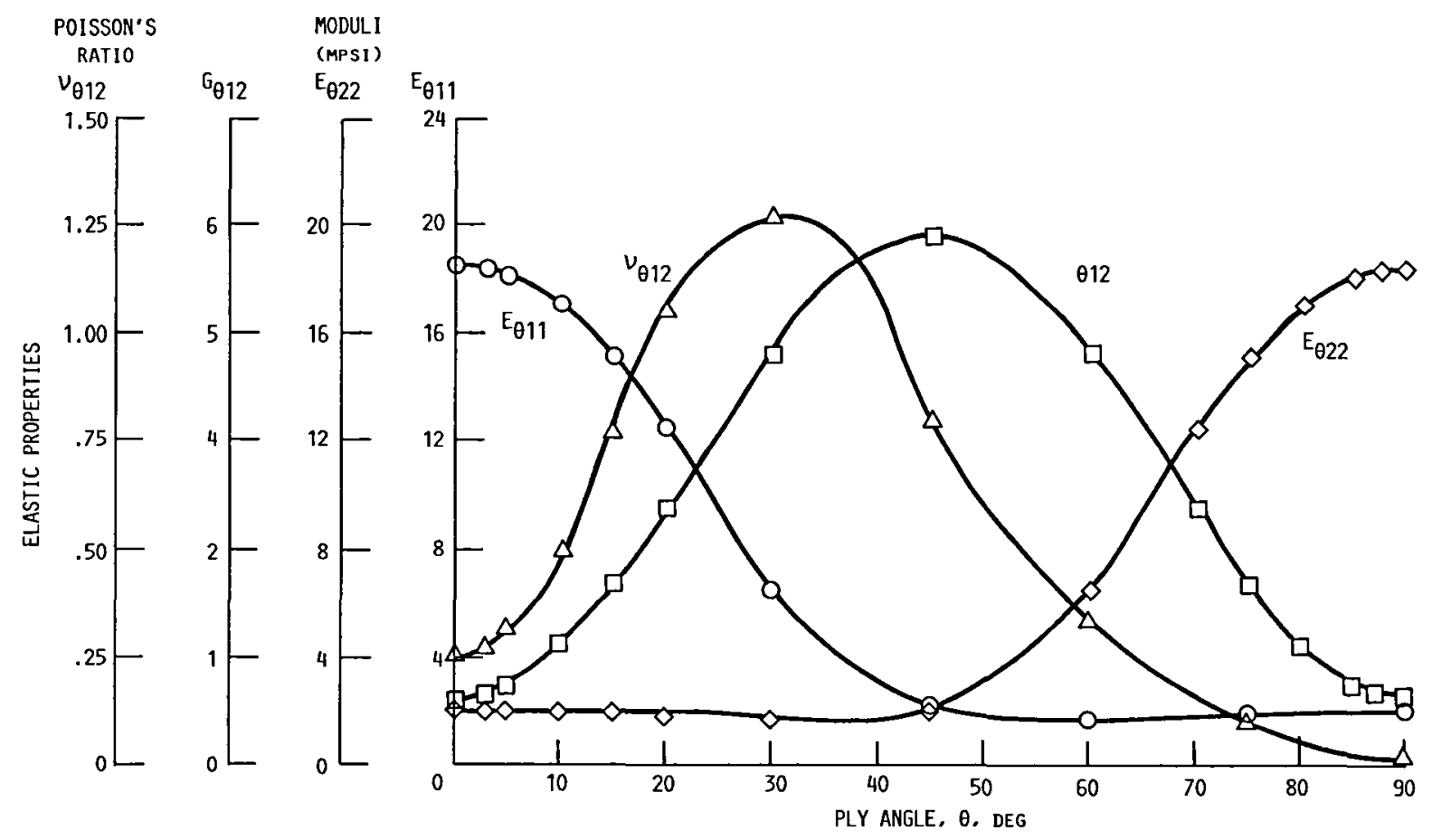

FIGURE 3. - ELASTIC PROPERTIES OF AS-GRAPHITE-FIBER/EPOXY (AS/E) $\pm \theta$ LAMINATES.

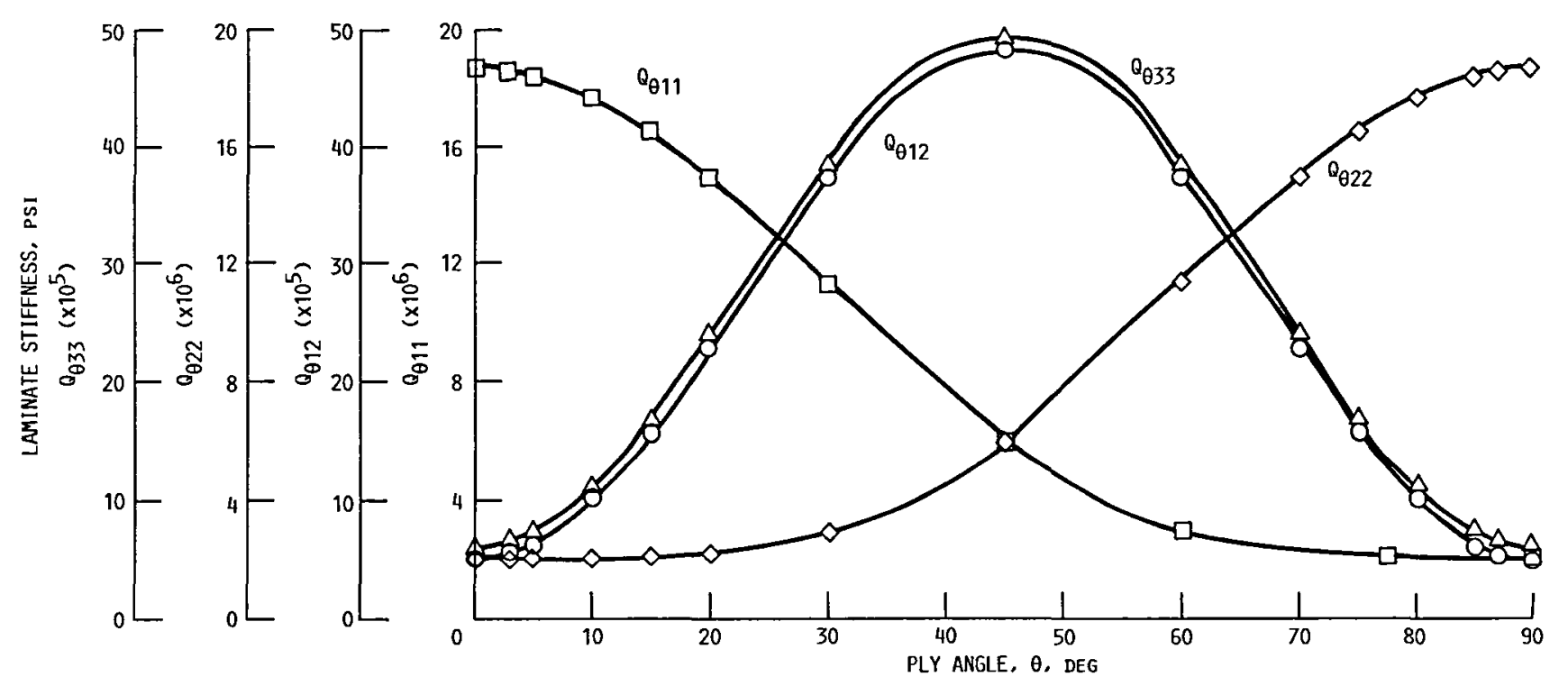

FIGURE 4. - REDUCED STIFFNESSES OF AS GRAPHITE-FIBER/EPOXY (AS/E) $\pm \theta$ LAMINATES. 


\begin{tabular}{|c|c|c|c|}
\hline \multicolumn{4}{|c|}{ Report Documentation Page } \\
\hline \begin{tabular}{l|l} 
1. Report No. & 2. Government Acc \\
NASA TM-100296 &
\end{tabular} & 2. Government Accession No. & \multicolumn{2}{|c|}{ 3. Recipient's Catalog No. } \\
\hline \multirow{2}{*}{\multicolumn{2}{|c|}{$\begin{array}{l}\text { 4. Title and Subtitle } \\
\text { Design Procedures for Fiber Composite Box Beams }\end{array}$}} & \multicolumn{2}{|c|}{$\begin{array}{l}\text { 5. Report Date } \\
\text { February } 1988\end{array}$} \\
\hline & & \multicolumn{2}{|c|}{ 6. Performing Organization Code } \\
\hline \multirow{2}{*}{\multicolumn{2}{|c|}{$\begin{array}{l}\text { 7. Author(s) } \\
\text { Christos C. Chamis and Pappu L. N. Murthy }\end{array}$}} & \multicolumn{2}{|c|}{$\begin{array}{l}\text { 8. Performing Organization Report No. } \\
\text { E-3296 }\end{array}$} \\
\hline & & \multicolumn{2}{|c|}{$\begin{array}{l}\text { 10. Work Unit No. } \\
505-53-11\end{array}$} \\
\hline \multirow{2}{*}{\multicolumn{2}{|c|}{$\begin{array}{l}\text { 9. Performing Organization Name and Address } \\
\text { Nationai Aeronautics and Space Administration } \\
\text { Lewis Research Center } \\
\text { Cleveland, Ohio } 44135-3191\end{array}$}} & \multicolumn{2}{|c|}{ 11. Contract or Grant No. } \\
\hline & & \multicolumn{2}{|c|}{$\begin{array}{l}\text { 13. Type of Report and Period Covered } \\
\text { Technical Memorandum }\end{array}$} \\
\hline \multicolumn{2}{|c|}{$\begin{array}{l}\text { 12. Sponsoring Agency Name and Address } \\
\text { National Aeronautics and Space Administration } \\
\text { Washington, D.C. 20546-0001 }\end{array}$} & \multicolumn{2}{|c|}{\begin{tabular}{|l} 
14. Sponsoring Agency Code \\
\end{tabular}} \\
\hline \multicolumn{4}{|c|}{$\begin{array}{l}\text { 15. Supplementary Notes } \\
\text { Christos C. Chamis, NASA Lewis Research Center; Pappu L.N. Murthy, Cleveland } \\
\text { State University, Civil Engineering Department, Cleveland, Ohio } 44115 \text {. }\end{array}$} \\
\hline \multicolumn{4}{|c|}{$\begin{array}{l}\text { 16. Abstract } \\
\text { Step-by-step procedures are described which can be used for the preliminary } \\
\text { design of fiber composite box beams subjected to combined loadings. These pro- } \\
\text { cedures include a collection of approximate closed-form equations so that all the } \\
\text { required calculations can be performed using pocket calculators. Included is an } \\
\text { illustrative example of a tapered cantilever box beam subjected to combined } \\
\text { loads. The box beam is designed to satisfy strength, displacement, buckling, and } \\
\text { frequercy requirements. }\end{array}$} \\
\hline 17. Key Words (Suggested by Author(s)) & \multirow{2}{*}{\multicolumn{3}{|c|}{$\begin{array}{l}\text { 18. Distribution Statement } \\
\text { Unclassified - unlimited } \\
\text { Subject Category } 24\end{array}$}} \\
\hline $\begin{array}{l}\text { Combined loads; Approximate equations; } \\
\text { Buckling loads; Vibration frequencies; } \\
\text { Ply strengths; Temperature; Moisture } \\
\text { displacements; Twist }\end{array}$ & & & \\
\hline \begin{tabular}{c|r} 
19. Security Classif. (of this report) & 20. Security Classif. (of \\
Unclass if ied & Uncl
\end{tabular} & sified & $\begin{array}{l}\text { 21. No of pages } \\
24\end{array}$ & $\begin{array}{r}\text { 22. Price* } \\
\text { A02. }\end{array}$ \\
\hline
\end{tabular}



National Aeronautics and

Space Administration

Lewis Research Center

Cleveland, Ohio 44135

Official Business

Penaity for Private Use $\$ 300$
SECOND CLASS MAIL

ADDRESS CORRECTION REQUESTED

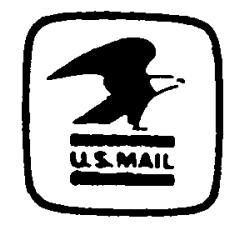

Postage and Fees Paj National Aeronautics an Space Administration NASA-451 